\title{
First Comprehensive Study on Total Determination of Nutritional Elements in the Fruit of the Campomanesia Adamantium (Cambess.): Brazilian Cerrado Plant

Nayara Vieira de Lima1, Daniela Granja Arakaki", Paula Fabiana Saldanha Tschinkel ${ }^{1}$, Anderson Fernandes da Silva1, Rita de Cássia Avellaneda Guimarães ${ }^{1}$, Priscila Aiko Hiane ${ }^{1}$, Marcos Antonio Ferreira Júnior ${ }^{2}$, Valter Aragão do Nascimento ${ }^{1}$

\section{Abstract}

Introduction: Fruits and leaves of Campomanesia adamantium (Cambess.) O. Berg commonly called guavira are used in dietary or as a mode of treatment of variety of ailments in indigenous and urban populations in the city of the Campo Grande, State of Mato Grosso do Sul, Brazil. However, comprehensive studies on their mineral composition are scarce.

Objective: In the present study, evaluation of mineral contents ( $\mathrm{Na}$, $\mathrm{K}, \mathrm{Ca}, \mathrm{Mg}, \mathrm{P}, \mathrm{Fe}, \mathrm{Zn}, \mathrm{Ni}, \mathrm{Mn}, \mathrm{Co}, \mathrm{Cu}, \mathrm{Mo}, \mathrm{Cr}$, Si and Al) from peel, pulp and seeds of guavira was carried out.

Method: The peel, pulp and seeds of guavira were studied by ICPOES with microwave digestion. The contents of the elements in the parts of the guavira, were compared to the Recommended Dietary Allowance (RDA), values Adequate Intake (Al) and tolerable upper intake levels (ULs).

Results: The results are considered in terms of the utility of the natural herbal medicaments as rich ( $\mathrm{Cu}, \mathrm{P}, \mathrm{Cr}$ and $\mathrm{Mo})$ or a source of minerals indispensable for proper functioning of the human organism. The concentration of elements in seeds, pulp and peel the guavira was compared with value of UL and does not cause toxicity. The concen-
1 Federal University of Mato Grosso do Sul, Campo Grande/MS, Brazil.

2 Federal University of Rio Grande do Norte, Natal/RN, Brazil.

Contact information:

Valter Aragão do Nascimento.

Address: Federal University of Mato Grosso do Sul, FAMED. Faculty of Medicine, Unit 9, PO Box 549, University City, Campo Grande/MS, Brazil, CEP 79070-900.

” aragao60@hotmail.com 
tration of elements $\mathrm{K}, \mathrm{Ca}, \mathrm{Na}, \mathrm{P}$ are found present at the major level in peel, pulp and seeds of fruit. The contents of Chromium $(\mathrm{Cr})$ were reportedly found higher than the permissible levels as recommended by the WHO.

Conclusion: The lack of knowledge of the elemental constituents of several species of medicinal plants often poses human lives at risk, these elements can also be dangerous and toxic, and involves global health problem. The gaps in knowledge about the level of contents in the Campomanesia adamantium (Cambess.) O. Berg was completed in this work. The data obtained would serve as a tool for deciding the dosage of prepared from this plant with medicinal and nutritional purposes.

\section{Keywords}

Medicinal Plants; Guavira; Inductively Coupled Plasma Mass Spectrometry.

\section{Introduction}

Medicinal plants are indispensable for human well being and provides all or a significant number of the remedies required in health care. Medicinal plants are used in treatment of complex diseases such as cancer [1], nutrition, flavoring, fragrances, cosmetics and other industrial purposes [2]. Several Brazilian Therapeutic plants and fruits are used as a mode of treatment of variety of ailments in indigenous and urban populations. Scientific researches have been made on traditional use of medicinal plants used in the Amazon [3-6], southern and northeast of Brazil [2-9]. However, the vegetation of Brazil has a lot of plants and tree species that are endemic. Most of these are little exploited. In general in the literature there are few reports on medicinal plants in the region Midwest Brazil, mainly involving the biome of pantanal and cerrado [3].

Campomanesia adamantium (Cambess.) O. Berg (Myrtaceae) is a bush that grows in the fields and pastures of Brazil's cerrado. This species belongs to the family Myrtaceae. Its fruits commonly called gabiroba, guabiroba or guavira. The fruits present oval shape, the pulp was succulent, with flavor wellappreciated. Its fruits are very much consumed by natives and sold to the public at the street-traders' stalls. Its fruits are used by urban and rural population to make juice, ice cream and in alcoholic drinks [10].

In Campo Grande, State of Mato Grosso do Sul, in Midwest Brazil, according to popular information, Campomanesia adamantium and its fruits are rich in Aluminum, Zinc, Phosphorus and Magnesium. Indigenous, rural and urban populations believe that guavira is rich in Iron and combats anemia. In this context, each chemical element has its chemical properties, health effects, and are associated with important applications in the treatment of ailments. Indeed, fruits are important sources of many nutrients, including Potassium, fiber and vitamin C. However, there are no scientific data confirming the concentration of these elements in the seeds, pulp and peel of guavira.

In folk medicine the leaves of Campomanesia adamantium (Cambess.) O. Berg and its fruits are used to treat urinary tract disease, inflammatory and obesity problems [11]. Preparation of the infusion of the leaves is used to control diarrhea, 
bladder problems, throat infections and vomiting [12]. Also is used in folk medicine to treat inflammation and rheumatism [13], anti-inflammatory and antinociceptive activities [14]. The compound cardamonin isolated from leaves of this plant showed antiproliferative activity in the cell line in a bioactivity-guided study [15]. In previous studies in vitro, the fruit extracts of $C$. adamantium were evaluated against the microorganism Mycobacterium tuberculosis [16]. Moreover, studies in animals showed that the fruit extracts of $C$. adamantium has anti-inflammatory, antihyperalgesic, and antidepressive properties in rodents without causing toxicity [17]. In the traditional medicine in Brazil, the root and leaves of Campomanesia adamantium $\mathrm{O}$. Berg are used for antidiabetic effects. The roots for $C$. adamantium is used to lowering lipid peroxidation and lipid serum level, improving risk factors for cardiometabolic diseases development [18]. The essential oils obtained from the leaves and flowers from Campomanesia adamantium (Myrtaceae) in the flowering stage were analyzed. The constituent major in the leaf oil was limonene and in the flower oil was ledol [19]. Limonene shown gastroprotective action in animals [20], while ledol was associated to antileukaemic effects [21]. Despite the existence of various species of plants and fruits that are used in the treatment of leukemia [22], knowing the concentration of elements is essential. According with others studies, the fruits have antioxidant properties; results showed the hepatoprotective effects of pulp or peel/seed hydroalcoholic extracts on injured liverderived HepG2 cells by CCl4. Partially, the result are associated with the presence of antioxidant compounds as flavonoids [23].

As noted on the above-mentioned findings, different studies have shown that fruits, roots, leaves, peel and pulp of Campomanesia adamantium (Cambess.) O. Berg (Myrtaceae) has medicinal properties but no elemental composition has been done. Minerals play a very important role in the formation of the active chemical constituents present in medicinal plants. They are essential to human health and have a preventive role in combating diseases, even though they comprise only $4-6 \%$ of the human body. It is very important, to know the concentration of Macroelements (Sodium (Na), Potassium (K), Calcium (Ca), Magnesium (Mg), Phosphorus (P)] and microelements [Iron (Fe), Manganese (Mn), Zinc (Zi), Cobalt (Co), Copper (Cu), Chromium (Cr), Lead (Pb), Nickel (Ni), Cadmium (Cd), Aluminum (Al), Selenium (Se), Sulfer (S), Arsenium (Ar), Molybdenum (Mo) in medicinal plants to estimate their role as sources of these components in the human diet. The lack of knowledge of the elemental constituents of these medicinal plants often poses human lives at risk, these elements can also be dangerous and toxic.

In Brazil, the dose rate of medicinal plants is not well defined [24]. These precautions are indispensable when larger amounts of fruits, leaves or others parts of the plant are consumed in long-term. Thus, know the concentrations of minerals in medicinal plants are very important and need to be screened for their toxicity. There are no studies that performed the comparisons on chemical composition of seeds, pulp and peel of the fruit of Campomanesia adamantium (Cambess.) O. Berg in Brazil with the international safety standards for the consumption of human beings.

The aim of present work was to compare the macroelements and micro-elements obtained in fruits of Campomanesia adamantium Cambess. 0. Berg used as treatment of ailments and foods by indigenous and urban communities of the Campo Grande, State of Mato Grosso do Sul, Brazil, with the limit specification of RDA/Al and the total daily intake of these minerals. The macro and microelements content, after microwave digestion, was determined by inductively coupled plasma - optical emission spectroscopy (ICP-OES). 


\section{Method}

\section{Research area}

Fruits of Campomanesia adamantium (Cambess.) $\mathrm{O}$. Berg were collected in December 2015 in the city of Campo Grande, State of Mato Grosso do Sul, Midwest region of Brazil. Fruits of the same ripening stage were collected from different plants. The Figure 1 shows the Location of Campo Grande on a map of Brazil. It is located $-20^{\circ} 26^{\prime} 34^{\prime \prime} S$ latitude and $-54^{\circ} 36^{\prime} 47^{\prime \prime} \mathrm{W}$ longitude and it is situated at elevation 592 meters above sea level.

In the Figure 2, there is one photo of fruit of the Campomanesia adamantium (Cambess.) O. Berg (on the left of Figure 2), popularly known as guavira from Cerrado, Campo Grande-MS, Brazil, on the right, the different parts (a) fruit of guavira, (b) peel and pulp guavira, (c) seed guavira. The specimen was identified by Arnildo Pott and deposited (No 53328) in the herbarium of the Federal University of Mato Grosso do Sul (UFMS)/Brazil.

\section{Elemental analysis by ICP-OES technique}

The peel, pulp and seed were removed and kept separately. The dried samples were then ground with a manual grinder into powder and sieve to get very fine powder. It was then weighed and digested in

Figure 1: Geographic coordinates of Campo Grande, State of Mato Grosso do Sul, Midwest region of Brazil.

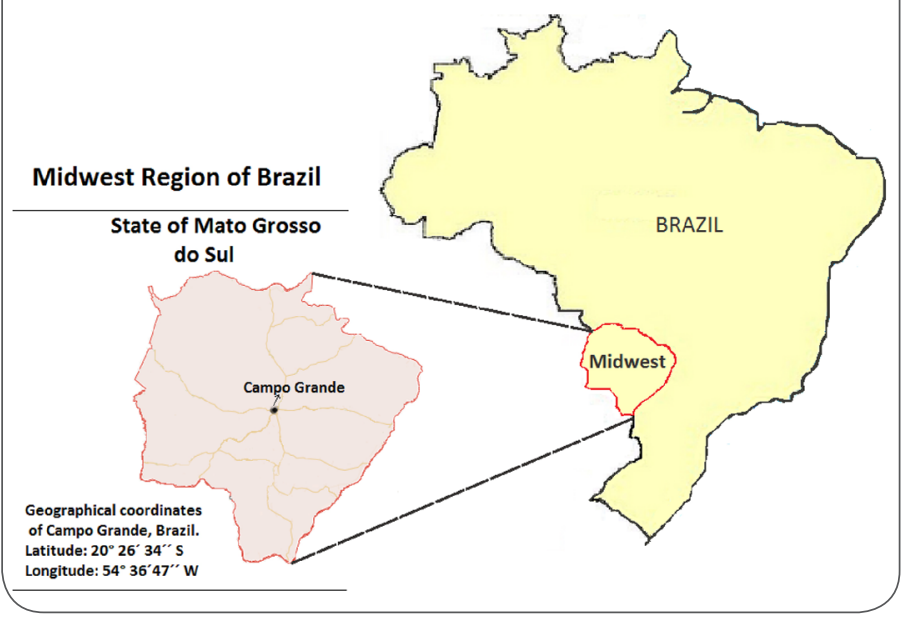

$\mathrm{HNO}_{3}+\mathrm{H}_{2} \mathrm{O}_{2}$ mixture. Samples were prepared as follows: processed with mixture of $0.5 \mathrm{~g}$ sample plus $5 \mathrm{~mL} \mathrm{HNO}_{3}$ (65\% Merck) and $3 \mathrm{~mL} \mathrm{H}_{2} \mathrm{O}_{2}$ (35\%, Merck Millipore) in the microwave digestion system Speedwave ${ }^{\circledR}$, Berghof, Germany. After digestion, samples were diluted to $100 \mathrm{~mL}$ with ultrapure water. Since the final acid concentration of the samples was quite high $\left(4 \% \mathrm{HNO}_{3}\right)$.

In the present paper, the concentration of the elements ( $\mathrm{K}, \mathrm{Ca}, \mathrm{Na}, \mathrm{P}, \mathrm{Mg}$, Fe, Si, Mo, Mn, Z, Cr, $\mathrm{Cu}, \mathrm{Al}$ and $\mathrm{Cu}$ ) was determined with the use of ICP-OES technique (Thermo Scientific - iCAP 6000 Series). The concentrations of the different elements in these samples were determined using the corresponding standard calibration curves obtained by using standard solutions of the elements of interest (Merck). Duplicate analyses were performed on each sample.

\section{Comparative criteria}

The contents obtained of the pulp, seeds and peel were compared with recommended values:

- Recommended Dietary Allowance (RDA): refer to the recommended average daily level of nutrients to meet the needs of nearly all healthy people in a particular age and gender group.

Figure 2: Campomanesia adamantium (Cambess.) O. Berg, popularly known as guavira from Cerrado, Campo Grande-MS, Brazil.

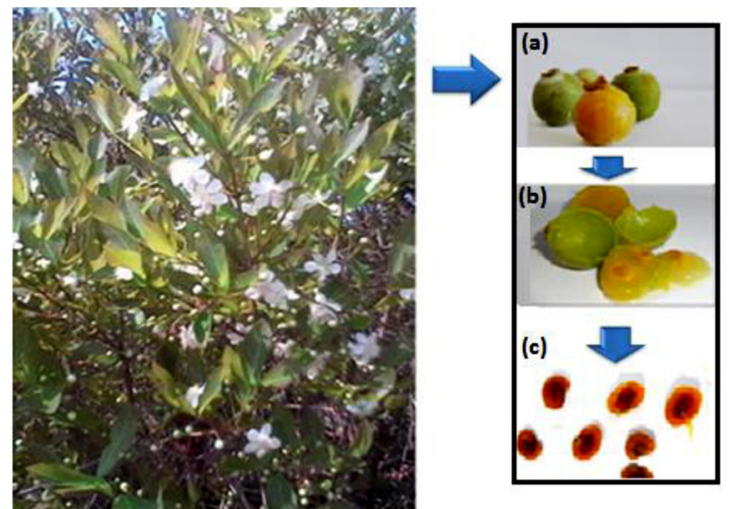

a) fruit of guavira, b) peel and pulp guavira, c) seed guavira. 
- Adequate Intake (AI): established when RDA is insufficient and is set at a level assumed to ensure nutritional adequacy. It is a recommended average daily nutrient intake level, based on experimentally derived intake levels or approximations of observed mean nutrient intake by a group (or groups) of apparently healthy people that are assumed to be adequate.

- Tolerable Upper Intake Level (UL): maximum daily intake of nutrients that do not pose a risk of adverse effects on health.

According to the recommended values, when the percentage of detected elements is greater than $15 \%$, it is considered as a food source. However, when the concentration of elements detected is greater than $30 \%$, it is considered as rich.

In the absence of established RDA or data on Adequate Intake (Al), some of values of concentration of macro and micro-nutrients obtained in this manuscript are compared with permissible limit set by FAO/WHO (Food and Agriculture Organization of the United Nations / World Health Organization) or with evidence of medicinal plants' results published.

\section{Results and Discussion}

The concentration of mineral in the seeds, pulp and peels guavira fruit obtained in this work and compared with the limit specification of RDA/AI and the total daily intake of these minerals are in the Table 1. The results obtained within the framework of this study were compared with the estimates based on the regulatory limits of the WHO/FAO and published studies involving medicinal plants when available in the literature. In the present work, the concentration of macro-elements in the peel, pulp and seeds decreases in the order: $\mathrm{K}>\mathrm{Ca}>\mathrm{Na}>$ $\mathrm{P}>\mathrm{Mg}, \mathrm{K}>\mathrm{P}>\mathrm{Na}>\mathrm{Ca}>\mathrm{Mg}$ and $\mathrm{P}>\mathrm{K}>\mathrm{Ca}$ $>\mathrm{Mg}>\mathrm{Na}$. As well as the concentration of micro elements in the peel, pulp and seeds also decreases in the order: $\mathrm{Fe}>\mathrm{Si}>\mathrm{Mo}>\mathrm{Mn}>\mathrm{Zn}>\mathrm{Cr}>$
Table 1. Elemental concentration $(\mathrm{mg} / 100 \mathrm{~g})$ of peel, pulp and seeds compared to Recommended Dietary Allowances/Adequate Intake and values tolerable upper intake level (UL).

\begin{tabular}{|c|c|c|c|c|c|}
\hline & $\begin{array}{c}\text { Peel } \\
\mathrm{mg} / 100 \mathrm{~g}\end{array}$ & $\begin{array}{c}\text { Pulp } \\
\mathrm{mg} / 100 \mathrm{~g}\end{array}$ & $\begin{array}{c}\text { Seeds } \\
\mathrm{mg} / 100 \mathrm{~g}\end{array}$ & $\begin{array}{c}\text { RDA/Al* } \\
\text { mg/day } \\
\text { (adults) }\end{array}$ & $\begin{array}{l}\text { UL mg/ } \\
\text { Day } \\
\text { (adults) }\end{array}$ \\
\hline \multicolumn{6}{|c|}{ Macro-elements } \\
\hline $\mathrm{Na}$ & 23.340 & 21.566 & 5.82 & $1,500 *$ & 2,300 \\
\hline $\mathrm{K}$ & 202.36 & 175.15 & 254.82 & $4,700 *$ & ND \\
\hline $\mathrm{Ca}$ & 25.980 & 19.900 & 46.080 & $1,000 *$ & 2,500 \\
\hline $\mathrm{Mg}$ & 15.304 & 10.371 & 19.81 & 355 & $350^{1}$ \\
\hline$P$ & 23.320 & 57.55 & 406.52 & 700 & 4,000 \\
\hline \multicolumn{6}{|c|}{ Micro-elements } \\
\hline $\mathrm{Fe}$ & 1.453 & 1.089 & 5.022 & 13 & 45 \\
\hline $\mathrm{Zn}$ & 0.118 & 0.221 & 1.063 & 9.5 & 40 \\
\hline $\mathrm{Ni}$ & ND & ND & 0.017 & ND & 1 \\
\hline $\mathrm{Mn}$ & 0.269 & 0.099 & 0.237 & $2.5^{\star}$ & 11 \\
\hline Co & 0.01 & 0.005 & 0.013 & ND & ND \\
\hline $\mathrm{Cu}$ & 0.05 & 0.031 & 0.326 & 0.9 & 10 \\
\hline Mo & 0.627 & 0.434 & 0.469 & 0.045 & 2 \\
\hline $\mathrm{Cr}$ & 0.101 & 0.074 & 0.084 & $0.030 *$ & ND \\
\hline Si & 1.346 & 1.182 & 1.104 & ND & ND \\
\hline
\end{tabular}

*No nutritional effect

\begin{tabular}{|l|l|l|l|l|l|}
\hline Al & ND & 0.597 & 2.037 & ND & 87.50 \\
\hline
\end{tabular}

*: The value for $\mathrm{Al}$ is presented where there are no RDA references available. 1: The UL for magnesium is determined by supplementation only and does not regard the ingestion from food or water. ND: Not determinable

$\mathrm{Cu}>\mathrm{Co}, \mathrm{Si}>\mathrm{Fe}>\mathrm{Al}>\mathrm{Mo}>\mathrm{Zn}>\mathrm{Mn}>\mathrm{Cr}>\mathrm{Cu}$ and $\mathrm{Fe}>\mathrm{Al}>\mathrm{Si}>\mathrm{Zn}>\mathrm{Mo}>\mathrm{Cu}>\mathrm{Mn}>\mathrm{Cr}>\mathrm{Ni}>$ $\mathrm{Co}$. Among the various elements $\mathrm{K}, \mathrm{Ca}, \mathrm{Na}, \mathrm{P}$ are found present at the major level, $\mathrm{Cr}$, $\mathrm{Cu}$ and $\mathrm{Co}$ are at minor level. Our studies demonstrated that the guavira seeds are rich in Copper, Iron, Phosphorus, chromium and molybdenum. However, this plant is not good source of other elements as Nickel, Zinc, Potassium, Magnesium, Manganese, Silicon, Sodium and Calcium.

In Table 1, a higher concentration of Sodium is found in the peel $23.34 \mathrm{mg} / 100 \mathrm{~g}$, while for pulp 
and seeds are $24.56 \mathrm{mg} / 100 \mathrm{~g}$ and $5.82 \mathrm{mg} / 100 \mathrm{~g}$. Considering the Adequate Intake of Sodium of $1,500 \mathrm{mg} /$ day, this fruit is not good source of Sodium. Moreover, the tolerable upper intake level (UL) for consuming of Sodium in adults is 2,300 $\mathrm{mg} /$ day. So, the results in Table 1 are below the values Adequate Intake and tolerable upper intake level. However, the results presented in Table 1 for Sodium concentration is higher than that obtained in other plants, such as the Terminalia chebula, with concentration of Sodium obtained of 0.06 $\mathrm{mg} / 100 \mathrm{~g}$ [25].

The concentrations of Potassium (K) in Table 1 were $254.8 \mathrm{mg} / 100 \mathrm{~g}, 202.3 \mathrm{mg} / 100 \mathrm{~g}$ and 175.15 $\mathrm{mg} / 100 \mathrm{~g}$ for guavira seeds, peel and pulp. These values are low when compared with others medicinal plants as Anethum graveolens (3,693.961 $\mathrm{mg} / 100 \mathrm{~g})$ and Allium cepa $(4,321.13 \mathrm{mg} / 100 \mathrm{~g})$ [26]. The fruit of guavira is not a source of Potassium, when considering the Adequate Intake of Potassium of 4,700 mg/day. The tolerable upper intake levels (UL) are not established for Potassium. However, several trials have evaluated the effects of Potassium supplementation [27].

On the other hand, minimum concentrations of Calcium were observed in the pulp (19.90 mg/100g) and maximum in seeds $(46.08 \mathrm{mg} / 100 \mathrm{~g})$, which is less than 1,334.3 mg/100g in Brassica campestris, Pakistani medicinal plant [28]. The reported tolerable upper intake level of Calcium is $2,500 \mathrm{mg} /$ day. It is clear that the concentration of Calcium in seeds, pulp and peel the guavira is lower than UL and does not cause toxicity. Calcium supplementation has been recommended for athletes who may require supplementation to improve bone density. In this case recommended daily dose of 1,500 mg [29]. However, higher doses cause a risk of serious gastrointestinal adverse event [30]. Until recently, the recommended adequate intake of Calcium for adults is 1,000 mg per day [31]. Based upon this information, the guavira is not considered a good source of Calcium.
In this study, in Table 1, a higher concentration of Magnesium is found in the seeds $19.81 \mathrm{mg} / 100 \mathrm{~g}$, while for pulp and peels are $10.37 \mathrm{mg} / 100 \mathrm{~g}$ and $15.30 \mathrm{mg} / 100 \mathrm{~g}$. This result is inside of the interval obtained by others papers published, for example, in some Pakistani medicinal plants, Magnesium content ranged between $0.373 \mathrm{mg} / 100 \mathrm{~g}$ in Punica granatum [32] to $224.188 \mathrm{mg} / 100 \mathrm{~g}$ in Convolvulus arsenis [28]. The Recommended Dietary Allowance (RDA) of Magnesium (Mg) for adults is established the mean intake of $355 \mathrm{mg} /$ day. So, the guavira fruit is not a good source of Magnesium. There is not current data to establish a safe upper level for the Magnesium intake. The UL for Magnesium is determined by supplementation only (350 mg/day) and does not regard the ingestion from food or water. Thus after this comparing, the contents of Magnesium obtained of the fruit of guavira do not cause toxicity.

The RDA for daily Phosphorus in adults is established the mean intake of 700 milligrams per day (see Table 1). From this comparison, the present study indicates that seeds of the guavira are rich in Phosphorus (406.52 mg/100g). Guavira have higher contents of Phosphorus than certain plants. In the case of Indian plant known as Sesbania bispinosa (Jacq.), the lowest concentration of Phosphorus was found in seeds $0.532 \mathrm{mg} / 100 \mathrm{~g}$ followed by the concentrations in leaves $0.292 \mathrm{mg} / 100 \mathrm{~g}$, in roots $0.28 \mathrm{mg} / 100 \mathrm{~g}$ [32]. The tolerable upper intake level (UL) for Phosphorus is $4,000 \mathrm{mg} /$ day for generally healthy adults. In this case specifically, the contents of Phosphorus obtained of the fruit not cause toxicity.

In Table 1, Iron contents were 1.453, 1.089 and $5.022 \mathrm{mg} / 100 \mathrm{~g}$ for the guavira peel, pulp and seed. Recommended Dietary Allowance (RDA) of Iron for adults is established the mean intake of $13 \mathrm{mg} /$ day. After comparison, the present study indicates that seeds of the guavira are rich in Iron. The regulatory limits of the WHO/FAO (2005) have not been established yet for the Iron in herbal medicines. The 
limited set by FAO/WHO (1984) in edible plants was $2 \mathrm{mg} / 100 \mathrm{~g}$. The Iron concentration found in Pakistani medicinal plants ranged with values between 18.163 and $679.688 \mathrm{mg} / 100 \mathrm{~g}$ [28]. However, the concentrations of Iron presented in the Table 1 are minor that the values tolerable upper intake level (45 mg/day), so that, concentration of Iron obtained in guavira don't cause toxicity.

In our work, in relation to guavira seeds were obtained the amount of Zinc $1.063 \mathrm{mg} / 100 \mathrm{~g}$, in the peel and pulp analyzed ranged between 0.0118 and $0.221 \mathrm{mg} / 100 \mathrm{~g}$. There are no limits of Zinc concentration in medicinal plants by the World Health Organization (WHO-2005). Recommended Dietary Allowance (RDA) of Zinc for adults is established the mean intake of $9.5 \mathrm{mg} /$ day. So, the guavira fruits are not rich in Zinc. However, the recommendation of Zinc is beneficial in the treatment of several disorders, such as several pro-inflammatory conditions and cancer [33]. In the Indian, the plant Withania somnifera known commonly as Indian ginseng has below concentration of Zinc in seeds $0.146 \mathrm{mg} / 100 \mathrm{~g}$ [34]. The concentrations of Zinc presented in the Table 1 are minor that the values tolerable upper intake level (40 mg/day), so that, concentration of Zinc obtained in guavira don't cause toxicity.

Nickel concentrations detected in the seeds of guavira were $0.017 \mathrm{mg} / 100 \mathrm{~g}$ (Table 1). Recommended Dietary Allowance (RDA) is not established for Nickel. According to Food and Agriculture Organization (FAO) of the United Nations (1984) the permissible limit in edible plants is $0.163 \mathrm{mg} / 100 \mathrm{~g}$. Until 2005, there are no limit permissible for Nickel by WHO in medicinal plants. Scientific findings have shown that $\mathrm{Ni}$ is toxic as evidenced by lipid peroxidative damage to placental membrane, in this case the metabolic change may be responsible for decreased placental viability, altered permeability, and potential subsequent embryotoxicity [36]. The concentration of Nickel presented in the Table 1 are below of the values tolerable upper intake level (1 mg/day), for that reason, concentration of
Nickel obtained in seeds of guavira don't cause toxicity.

In Table 1, Manganese (Mn) contents were 0.269, 0.099 and $0.237 \mathrm{mg} / 100 \mathrm{~g}$ for the guavira peel, pulp and seed. According to FAO/WHO the permissible limit set in edible plants was $0.2 \mathrm{mg} / 100 \mathrm{~g}$ [35]. After this comparison, the concentrations of Manganese in fruits of guavira are in perfect harmony with those limits of FAO/WHO. However, for Manganese in medicinal plants limits not yet been established by WHO (2005). Considering the Adequate Intake of Manganese of $2.5 \mathrm{mg} / \mathrm{day}$, this fruit is not good source of Manganese. The tolerable upper intake level (UL) for consuming of Manganese in adults is $11 \mathrm{mg} /$ day. So, the results in Table 1 for Manganese are below the values Adequate Intake and tolerable upper intake level.

The contents of Cobalt varied from $0.01 \mathrm{mg} / 100$ $\mathrm{g}$ in the peel, to $0.005 \mathrm{mg} / 100 \mathrm{~g}$ in the pulp and $0.013 \mathrm{mg} / 100 \mathrm{~g}$ in the seeds. Results on Mentha piperita shown $0.026 \mathrm{mg} / 100 \mathrm{~g}$ of Cobalt in a Spanish study [36]. A safe Recommended Dietary Allowance (RDA) or Adequate Intake for Cobalt (Co) hasn't been set yet. The only role for Cobalt is a constituent of vitamin B12 [37]. Neither has Cobalt been assessed in relation to the WHO Guidelines for Drinking-water. Until now, Cobalt has not been evaluated by competent organs in order to establish a tolerable upper intake level. However, some reports have suggested that acute intakes following ingestion of $>30 \mathrm{mg}$ Co/day may cause skin rashes and gastrointestinal upset in humans [38].

Copper (Cu) contents were $0.005 \mathrm{mg} / 100 \mathrm{~g}$, $0.0031 \mathrm{mg} / 100 \mathrm{~g}$, and $0.0326 \mathrm{mg} / 100 \mathrm{~g}$ for the guavira peel, pulp and seed respectively. In our study, Copper content in peel and pulp are lesser than seeds. The Recommended Dietary Allowance (RDA) of Copper for adults is established the mean intake of $0.9 \mathrm{mg} /$ day. The present results indicate that seeds of guavira are rich in cooper. In a recent study in Serbia, the concentration of Copper in Foeniculum vulgare was mentioned as 
$0.1542 \mathrm{mg} / 100 \mathrm{~g}$ [39]. The permissible limit of Copper set by FAO/WHO (1984) in edible plants is 0.3 $\mathrm{mg} / 100 \mathrm{~g}$. The WHO limit for Copper in medicinal herbs has not been established yet. However, some countries had set limits for Copper in medicinal plants at 20 and $0.150 \mathrm{mg} / \mathrm{g}$, respectively [40]. The tolerable upper intake level (UL) for consuming of Copper in adults is $10 \mathrm{mg} /$ day. So, the results in Table 1 for Copper are below the values Adequate Intake and tolerable upper intake level.

Molybdenum (Mo) contents in the guavira peel, pulp and seed were 0.626, 0.434 and 0.469 mg/100g respectively (see Table 1 ). The Recommended Dietary Allowance (RDA) of Molybdenum for adults is established the mean intake of 0.045 $\mathrm{mg} / \mathrm{day}$. The present results indicate that seeds, pulp and peel of guavira are rich in Molybdenum. In 1973, the WHO experts suggested that $2 \mu \mathrm{g} / \mathrm{kg}$ of body weight would be appropriate to maintain normal parameters in health [41]. In some countries the concentration of molybdenum in diet $0.23 \mathrm{mg} / \mathrm{kg}$, this corresponds to a daily intake of $100 \mu \mathrm{g}$ of molybdenum per day for adults. Studies on consumption fruits or leaves containing Molybdenum are scarce in the literature reports, and the values of dietary intake considering desirable (elements essential or beneficial to plants or animals) and undersirable (with intoxication risk) are yet incomplete. This is important information required in assessing risks to human health due to their overburden. So, knowledge of the current levels of dietary intake of guavira by Indigenous and rural populations are of primary importance [42]. The tolerable upper intake level (UL) for consuming of Molybdenum in adults is $2 \mathrm{mg} /$ day. So, the results in Table 1 for Molybdenum are below the values Adequate Intake and tolerable upper intake level.

In Table 1, Chromium ( $\mathrm{Cr}$ ) contents were 0.101, 0.074 , and $0.084 \mathrm{mg} / 100 \mathrm{~g}$ for the guavira peel, pulp and seed. Considering the Adequate Intake of Chromium of $0.030 \mathrm{mg} / \mathrm{day}$, all parts of this fruit is rich in Chromium. On others hand in the Pakistan, the range of Chromium varied between $0.12 \mathrm{mg} / 100 \mathrm{~g}$ in Convolvulus arvensis and 2.949 $\mathrm{mg} / 100 \mathrm{~g}$ in Cannabis sativa [28]. The permissible limit set by FAO/WHO (1984) in edible plants was $0.002 \mathrm{mg} / 100 \mathrm{~g}$. The permissible limit of Chromium for plants is $0.130 \mathrm{mg} / 100 \mathrm{~g}$ recommended by $\mathrm{WHO}$. After cooperation, our results indicate that concentration of Chromium in fruit peel was well above the permissible limit set by WHO. Moreover, the tolerable upper intake level (UL) for consuming of Chromium in adult is not established yet. In individuals with type 2 diabetes were observed the beneficial effects of supplemental chromium [43].

According to data in Table 1, the range of Silicon (Si) varied with values between $1.346 \mathrm{mg} / 100 \mathrm{~g}$ (peel), $1.182 \mathrm{mg} / 100 \mathrm{~g}$ (pulp) and $1.104 \mathrm{mg} / 100 \mathrm{~g}$ in guavira seeds. There are no guidelines to establish a permissible level of Silicon in herbs medicinal. A safe Recommended Dietary Allowance (RDA) or Adequate Intake for Silicon (Si) hasn't been set yet. The daily intake from the British diet has been estimated to $20-50 \mathrm{mg}$ corresponds to $0.3-0.8 \mathrm{mg} /$ $\mathrm{kg}$ body weight/day in a $60 \mathrm{~kg}$ person [44]. Since Silicon is not considered an essential element, most plants will grow normally without it. Studies on deprivation of Silicon in humans have not been conducted. However, its have a beneficial role in bone health [45].

In Table 1 Aluminum (Al) contents were 0.567, and $2.037 \mathrm{mg} / 100 \mathrm{~g}$ for the guavira pulp and seed. There are not Recommendation (RDA) and Adequate Intake for Aluminum (Al). According to FDA's 1993 Total Diet Study dietary exposure model and the 1987-1988 U.S. Department of Agriculture (USDA) Nationwide Food Consumption Survey, the authors estimated daily Aluminum intakes $0.12 \mathrm{mg}$ Al/kg/day for adult males and females. [46]. However, excessive intake of Aluminum results in pathological aberrations such amnesia in young people. Aluminum is present in the brain of patients with 
Alzheimer disease [47]. Aluminum has found numerous applications in moderna pharmacology [48]. Clinical trials suggest that administration of medications containing Aluminum and citrate or beverages cause toxicity [49].

\section{Conclusion}

For the first time, the concentration of macro and micro-elements in seeds, pulp and peel in the Campomanesia adamantium (Cambess.) O. Berg (Myrtaceae) were measured and compared with recommended values. Parts of the fruit as seeds only are rich in Phosphorus, Iron and Copper. However, peel, pulp and seeds area rich in Molybdenum and Chromium. All contents are below the values Adequate Intake (Al) and tolerable upper intake level (UL).

The analysis of $\mathrm{Cr}$ concentration showed higher in peel and the lowest value was found in pulp. It was found that highest amount of Mo was present in peel and pulp had the lowest value. The contents of Chromium ( $\mathrm{Cr}$ ) were reportedly found higher than the permissible levels as recommended by the WHO. However, others values of concentration of macro and micro-nutrients obtained in this work are according to permissible limit set by FAO/ WHO or with studies published of medicinal plants.

The concentration of elements $\mathrm{K}, \mathrm{Ca}, \mathrm{Na}, \mathrm{P}$ are higher in peel, pulp and seeds of fruit. The level of Zinc and Copper present in some parts of fruit is very low compared to other detected elements.

The mineral composition results of the guavira showed that their fruits are not source of mineral elements as $\mathrm{Zn}, \mathrm{Ca}, \mathrm{K}, \mathrm{Na}, \mathrm{Ni}, \mathrm{Mn}, \mathrm{Co}, \mathrm{Mg}, \mathrm{Al}$ and Si.

The gaps in knowledge about the level of contents in the Campomanesia adamantium (Cambess.) O. Berg was completed in this work. The data obtained would serve as a tool for deciding the dosage of prepared from this plant with medicinal and nutritional purposes.
The knowledge of the chemical composition and medicinal properties of various plants has economic interest crop production and global health.

\section{References}

1. Monteiro LS, Bastos KX, Barbosa-Filho JM, Athayde-Filho PF, Diniz MFFM, Sobral MV. Medicinal Plants and Other Living Organisms with Antitumor Potential against Lung Cancer. Evidence-Based Complementary and Alternative Medicine. 2014; 2014:1-15. https://www.hindawi.com/journals/ecam/2014/604152/abs/

2. Calixto, JB. Medicinal plants for Forest conservation and health care. Brazilian Journal of Medical and Biological Research. 2000; 33(2).

3. Di Stasi LC, Hiruma CA, Guimarães EM, Santos CM. Fitoterapia. 1994; 65: 529-540.

4. Kffuri CW, Lopes MA, Ming LC, Odonne G, Kinupp VF. Antimalarial plants used by indigenous people of the Upper Rio Negro in Amazonas, Brazil. Journal of Ethnopharmacology. 2016; 178: 188-198. http://www.sciencedirect.com/science/ article/pii/S0378874115302506

5. Oliveira DR, Krettli AU, Aguiar ACC, Leitão GG, Vieira MN, Martins KS, et al. Ethnopharmacological evaluation of medicinal plants used against malaria by quilombola communities from Oriximiná, Brazil. Journal of Ethnopharmacology. 2015; 173: 424-434. http://www.sciencedirect.com/science/article/pii/ S0378874115300520

6. Coelho-Ferreira M. Medicinal knowledge and plant utilization in an Amazonian coastal community of Marudá, Pará State (Brazil). Journal of Ethnopharmacology. 2009; 126: 159-175. http:// www-sciencedirect-com.ez51.periodicos.capes.gov.br/science/ article/pii/S0378874109004292

7. Trojan-Rodrigues M, Alves TLS, Soares GLG, Ritter MR. Plants used as antidiabetics in popular medicine in Rio Grande do Sul, southern Brazil. Journal of Ethnopharmacology. 2012; 139:155163. http://www-sciencedirect-com.ez51.periodicos.capes.gov. br/science/article/pii/S0378874111007732

8. Saraiva ME, de Alencar Ulisses AVR, Ribeiro DA, de Oliveira LGS, de Macêdo DG, de Sousa FDFS, et al. Plant species as a therapeutic resource in areas of the savanna in the state of Pernambuco, Northeast Brazil. Journal of Ethnopharmacology, 2015; 171: 141-153. http://www.sciencedirect.com/science/ article/pii/S0378874115003669

9. Agra MDF, Baracho GS, Nurit K, Basílio IJLD, Coelho VPM. Medicinal and poisonous diversity of the flora of "Cariri Paraibano", Brazil. Journal of Ethnopharmacology. 2007; 111(2): 383-395. http://www.sciencedirect.com/science/article/ pii/S0378874106006386

10. Vallilo MI, Lamardo LCA, Gaberlotti ML, Oliveira ED, Moreno $\mathrm{PRH}$. Composição química dos frutos de Campomanesia adamantium (Cambessédes) O. Berg. Ciência e Tecnologia de Alimentos. 2006; 26(4): 725-955. http://www.scielo.br/pdf/cta/ v26n4/14.pdf 
11. Rodrigues VEG, Carvalho DA. Plantas medicinais no domínio dos cerrados. Lavras: Ed. UFLA, 2001.

12. Michel MC, Guimarães AG, Paula CA, Rezende SA, Sobral ME, Guimarães DA. Extracts from the leaves of Campomanesia velutina inhibits production of LPS/INF- $\gamma$ induced inflammatory mediators in J774A. 1 cells and exerts anti-inflammatory and antinociceptive effects in vivo. Revista Brasileira de Farmacognosia. 2013; 23(6): 927-936. http://www.scielo. br/scielo.php?pid=S0102-695X2013000600927\&script=sci arttext\&tlng=pt

13. Lorenzi H. Árvores Brasileiras: Manual de Identificação e Cultivo de Plantas Arbóreas Nativas do Brasil. Nova Odessa, São Paulo: Ed. Plantarum, 1992.

14. Ferreira LC, Grabe-Guimaraes A, de Paula CA, Michel MCP, Guimaraes RG, Rezende SA, Souza Filho JD, Saude-Guimaraes DA. Anti-inflammatory and antinociceptiveactivities of Campomanesia adamantium. Journal of Ethnopharmacology. 2013; 145: 100-108. http://www-sciencedirect-com.ez51. periodicos.capes.gov.br/science/article/pii/S0378874112007349

15. Pascoal ACRF, Ehrenfried CA, Lopez BGC, Araujo TM, Pascoal VDB, Gilioli R, et al. Antiproliferative Activity and Induction of Apoptosis in PC-3 Cells by the Chalcone Cardamonin from Campomanesia adamantium (Myrtaceae) in a BioactivityGuided Study. Molecules. 2014; 19: 1843-1855. http://www. mdpi.com/1420-3049/19/2/1843/htm

16. Pavan FR, Leite CQF, Coelho RG, Coutinho ID, Honda NK, Cardoso $C A L$, et al. Evaluation of anti-mycobacterium tuberculosis activity of Campomanesia adamantium (Myrtaceae). Quimica. Nova. 2009; 32(5): 1222-1226. http://www.scielo.br/scielo. php?pid=S0100-40422009000500026\&script=sci_arttext

17. de Souza JC, Piccinelli AC, Aquino DFS, de Souza VV, Schmitz WO, Traesel GK, Cardoso CAL, Kassuya CAL, Arena AC. Toxicological analysis and antihyperalgesic, antidepressant, and anti-inflammatory effects of Campomanesia adamantium fruit barks. Nutritional Neuroscience. 2016. http://www. tandfonline.com/doi/pdf/10.1179/1476830514Y.0000000145? needAccess $=$ true

18. Espindola PPDT, Rocha PDSD, Carollo CA, Schmitz WO, Pereira $Z V$, Vieira $M D C$, et al. Antioxidant and Antihyperlipidemic Effects of Campomanesia adamantium O. Berg Root. Oxidative Medicine and Cellular Longevity. 2016. https://www.hindawi. com/journals/omcl/2016/7910340/abs/

19. Coutinho ID, Poppi NR, Cardoso CL. Identification of the Volatile Compounds of Leaves and Flowers in Guavira (Campomanesia adamantium O. Berg.). Journal of Essential Oil Research. 2008; 20(5): 405-407.

20. Moraes TM, Kushima H, Moleiro FC, Santos RC, Rocha LRM, Marques $\mathrm{MO}$, et al. Effects of limonene and essential oil from Citrus aurantium on gastric mucosa: role of prostaglandins and gastric mucus secretion. Chemico-Biological Interactions. 2009; 180(3): 499-505. http://www-sciencedirect-com.ez51.periodicos.capes.gov.br/science/article/pii/S0009279709001677
21. Nibret E, Wink M. Trypanocidal and antileukaemic effects of the essential oils of Hageniaabyssinica, Leonotisocymifolia, Moringastenopetala, and their main individual constituents. Phytomedicine. 2010; 17(12): 911-920. http://www-sciencedirect-com.ez51.periodicos.capes.gov.br/science/article/pii/ S0944711310000565

22. Saedi, TA, Md Noor S, Ismail P, Othman F. The effects of herbs and fruits on leukaemia. Evidence-Based Complementary and Alternative Medicine, 2014; 2014: 1-8. https://www.hindawi. com/journals/ecam/2014/494136/abs/

23. de Oliveira Fernandes T, de Ávila RI, de Moura SS, de Almeida Ribeiro G, Naves MMV, Valadares MC. Campomanesia adamantium (Myrtaceae) fruits protect HEPG2 cells against carbon tetrachloride-induced toxicity. Toxicology Reports, 2015; 2: 184-193. http://www-sciencedirect-com.ez51.periodicos. capes.gov.br/science/article/pii/S221475001400153X

24. Carvalho ACB, Ramalho LS, de Oliveira Marques RF, Perfeito JPS. Regulation of herbal medicines in Brazil. Journal of Ethnopharmacology, 2014; 158: 503-506. http://wwwsciencedirect-com.ez51.periodicos.capes.gov.br/science/article/ pii/S0378874114006138

25. Aziz MA, Adnan M, Begum S, Azizullah A, Nazir R, Iram S. A review on the elemental contents of Pakistani medicinal plants: Implications for folk medicines. Journal of Ethopharmacology. 2016; 188: 177-192. http://www-sciencedirect-com.ez51. periodicos.capes.gov.br/science/article/pii/S0378874116302744

26. Khan SA, Ahmad I, Mohajir MS. Evalluation of mineral contents of some edible medicinal plants. Pakistan Journal of Pharmaceutical Sciences. 2006; 19: 141-148. http://www.pjps. pk/wp-content/uploads/pdfs/CD-PJPS-19-2-06/Paper-12.pdf

27. Siani A, Strazzullo P, Giacco A, Pacioni D, Celentano E, Mancini $M$. Increasing the dietary Potassium intake reduces the need for antihypertensive medication. Annals of internal medicine, 1991;115(10): 753-759. http://annals.org/article. aspx?articleid $=705137$

28. Jabeen S, Shah MT, Khan S, Hayat MQ. Determination of major and trace elements in ten important folk therapeutic plants of Haripur basin, Pakistan. Journal of Medicinal Plants Research. 2010; 4(7): 559-566. http://www.academicjournals.org/journal/ JMPR/article-full-text-pdf/603FEB617201

29. Austin K, Seebohar B. Performance Nutrition: Applying the Science of Nutrient Timing. 1st ed. Ed. Human Kinetics; 2011.

30. Wolf SM. Worst Pills, Best Pills: A Consumer's Guide to Avoiding Drug-Induced Death or Illness. Revised ed. New York: Pocket Books; 2005

31. Crook MA. Clinical Chemistry and Metabolic Medicine. 7th ed. London: Ed. Holder Arnold; 2006.

32. Parab N, Vaidya S. Determination of Some Trace Elements and Macro Minerals of Sesbania bispinosa (Jacq.) W. F. Wight. International Journal of Pharmacy and Pharmaceutical Research. 2016; 6(2): 383-401. http://ijppr.humanjournals.com/wpcontent/uploads/2016/06/31. Neelam-Parab-Sharda-Vaidya.pdf 
33. Connell P, Young VM, Toborek M, Cohen DA, Barve S, McClain $C J$, et al. Zinc attenuates tumor necrosis factor-mediated activation of transcription factors in endothelial cells. Journal of the American College of Nutrition. 1997; 16(5): 411-417. http://www.tandfonline.com/doi/abs/10.1080/07315724.1997 .10718706

34. Gupta J. Trace Metal Analysis in Withania somnifera. Oriental Journal of Chemistry. 2013; 29(3): 1099-1101. http://www. orientjchem.org/vol29no3/trace-metal-analysis-in-withaniasomnifera/

35. Omokehide A, Lajide L, Hammed O, Babatunde O. Trace Elements and Majors Minerals Evaluation in Fleurya aestuans Linn. (Urticaceae). International Journal of Pharma Sciences. 2013; 3 (5): 328-332. http://ijps.aizeonpublishers.net/content/2013/5/ ijps328-332.pdf

36. Rubio C, Lucas JRD, Gutiérrez AJ, Glez-Weller D, Marrero BP, Caballero JM, et al. Evaluation of metal concentrations in mentha herbal teas (Mentha piperita, Mentha pulegium and Mentha species) by inductively coupled plasma spectrometry. Journal of pharmaceutical and biomedical analysis. 2012; 71: 11-17. http://www-sciencedirect-com.ez51.periodicos.capes. gov.br/science/article/pii/S0731708512004219

37. Clydesdale FM, Francis FJ. Food nutrition and health. Springer Science \& Business Media, 2012

38. Carson BL, Ellis HV, McCann JL. Toxicology and Biological Monitoring of Metals in Humans. Chelsea, Ml: Lewis Publishers, 1986.

39. Stanojkovic-Sebic A, Pivic R, Josic D, Dinic Z, Stanojkovic A. Heavy Metals Content in Selected Medicinal Plants Commonly Used as Components for Herbal Formulations. Journal of Agricultural Sciences. 2015; 21: 317-325

40. Ullah R, Khader JA, Hussain I, Talha NMA, Khan N. Investigation of macro and micro-nutrients in selected medicinal plants. African Journal of Pharmacy and Pharmacology. 2012; 6(25): 1829-1832. http://www.academicjournals.org/journal/AJPP/ article-abstract/72160C631892

41. World Health Organization: 1992. Trace elements in human nutrition. Geneva. http://www.fao.org/3/a-u5900m/u5900t05. htm

42. Bratter $P$, Schramel $P$, editors. Trace element analytical chemistry in medicine and biology. Berlin: Walter De Gruyterlnc; 1987. An international collaborative research programme on minor and trace elements in total diets; p. 157-165.

43. Anderson RA, Cheng N, Bryden NA, Polansky MM, Cheng $\mathrm{N}$, Chi J, et al. Elevated intakes of supplemental chromium improve glucose and insulin variables in individuals with type 2 diabetes. Diabetes.1997; 46(11): 1786-1791. http://diabetes. diabetesjournals.org/content/46/11/1786.short
44. Bellia JP, Newton K, Davenport A, Birchall JD, Roberts NB. Silicon and aluminium and their inter-relationship in serum and urine after renal transplantation. European journal of clinical investigation, 1994; 24(10), 703-710. http://onlinelibrary-wiley-com.ez51. periodicos.capes.gov.br/doi/10.1111/j.1365-2362.1994. tb01064.x/abstract

45. Carlisle EM. Silicon: an essential element for the chick. Science.1972; 178: 619-621. http://science-sciencemag-org. ez51.periodicos.capes.gov.br/content/178/4061/619

46. US Department of Health and Human Services: 1999. Toxicological profile for Aluminum. Atlanta: US Department of Health and Human Services, Agency for Toxic Substances and Disease Registry, Public Health Service.

47. Exley C, Birchall JD. The cellular toxicity of aluminium. Journal of theoretical biology. 1992; 159(1): 83-98. http://wwwsciencedirect-com.ez51.periodicos.capes.gov.br/science/article/ pii/S0022519305807696

48. Gielen M, Tiekink ERT (Eds). Metallotherapeutic Drugs \& Metalbased Diagnostic Agents, The use of Metals in Medicine. John Wiley \& Sons; 2005. Chapter 4, Aluminium; p. 65-82.

49. Fairweather-Tait S, Hickson K, McGaw B, Reid M. Orange juice enhances aluminium absorption from antacid preparation. European journal of clinical nutrition. 1994; 48(1), 71-73. http://europepmc.org/abstract/med/8200332

\section{Publish in International Archives of Medicine}

International Archives of Medicine is an open access journal publishing articles encompassing all aspects of medical science and clinical practice. IAM is considered a megajournal with independent sections on all areas of medicine. IAM is a really international journal with authors and board members from all around the world. The journal is widely indexed and classified Q2 in category Medicine. 